\title{
Psychiatry and Surrealism
}

\author{
Patrick Bracken, Senior House Officer in Psychiatry, Cork Regional Hospital, Wilton, Cork
}

A recent edition of the Bulletin contained a letter ${ }^{1}$ which was originally published in La Révolution Surréaliste 60 years ago. The letter was probably written by André Breton and was basically an attack on psychiatry as then practised in France and in particular on the process of involuntary admission. The letter appeared in the Bulletin under the title 'An Historical Vignette: Surrealism and Anti-Psychiatry'. While there can be little doubt that the surrealists were antagonistic to psychiatry I would like to argue that a great deal of their work is of potential interest to psychiatrists. The surrealist movement was opposed to any form of rationalism. It was opposed to anything which could possibly limit the imagination and this was the source of its conflict with psychiatry. But surrealist art and literature was essentially an exploration of the bizarre, the irrational and the unconscious and these are subjects which are, of necessity, of importance to the psychiatrist and the psychotherapist.

Andre Breton, who was to be the main theoretician of surrealism, was himself training to be a psychiatrist at the end of the first World War. While working at the neurological centre in Nantes in 1916 he became familiar with Freud's theories and had occasion to practise psychotherapy on the wounded in the hospital. It was here too that he met the poet Jacques Vache who was a patient at that time. Vache introduced Breton to the various contemporary movements in poetry and had a huge influence on his intellectual development. By 1919, while still preoccupied with Freud, Breton was beginning to turn his interests from medicine to literature, and psychoanalysis was to provide him with a convenient bridge between the scientific attitude of medicine and the introspective approach of the poet. Indeed Freud was to grant Breton an interview, in 1921, at the poet's request. Freud was later to confess that it was not at all clear to him what surrealism was about. 'Perhaps I am not made to understand it', he said, 'for I am so far removed from art'. ${ }^{2}$ In spite of this apparent lack of interest on Freud's behalf, surrealism began to develop artistic and poetic techniques which were similar to the therapeutic procedures of psychoanalysis.

The surrealists began to explore their dreams and used their dream-images in their poetry and painting. Breton's book Les Vases Communicants, which was dedicated to Freud, was a statement of the surrealist approach to dreams. He noted the same type of displacement and condensation occurring in poetic images as Freud had noted in dreams. However while psychoanalysis used dreams in the process of interpretation, surrealism was to use dreams for creative purposes. In the First Manifesto of Surrealism one finds the famous lines 'I believe in the future resolution of these two states, dream and reality, which are seemingly so contradictory, into a kind of absolute reality, a surreality, if one may so speak'. ${ }^{3}$ For the surrealists our experiences while asleep have a similar, if not greater, significance as our experiences while fully awake and concious. Their aim in using dream-images was to inflate waking reality with some of the irrationality and emotion commonly found in dreams. While this can in some ways be seen as the opposite of psychotherapy, which usually aims to replace id-driven behaviour by rational considerations under ego control, Breton does imply a 'therapeutic' role for this form of artistic practice in the Second Surrealist Manifesto when he stated that a person, endowed with any artistic gift, can 'rather than transform his dreams into symptoms, transform them into artistic creations. Thus, he can escape the fate of neurosis and, through this detour, make contact with reality'.

Another practice of surrealism which was influenced by psychoanalysis was that of automatic writing. This was very similar to free association and involved the poet trying to shut out all outside distractions and producing a stream of words and images by the free play of association, not under conscious control. These productions would later be used as poems themselves or else incorporated into larger poems.

A third form of psychoanalytic experimentation was the voluntary simulation of states of mental abnormality. In 1930 Breton published The Immaculate Conception which was a series of attempts at such simulation. Emil Kraepelin's Lectures On Clinical Psychiatry was an important classificatory source. ${ }^{3}$ In this work Breton explored the relationship between poetic creativity and the various forms of psychopathology. The experiment was reported sympathetically in Annales Médico-Psychologiques by several psychiatrists including Jacques Lacan. ${ }^{6}$ The surrealist painter Salvador Dali was perhaps the most flamboyant in the use of this technique. Dali was also greatly influenced by Freud and many of his paintings contain images which can be explored and interpreted along analytic lines. Dali also met Freud and, unlike Breton, his admiration seems to have been reciprocated to some extent. After their meeting Freud wrote to a friend 'I owe you a thanks for bringing yesterday's visitor. For until now, I have been inclined to regard the surrealists... as complete fools. That young Spaniard, with his candid, fanatical eyes and his undeniable technical mastery has changed my estimate. It would indeed be interesting to investigate analytically how he came to create that picture....$^{7}$

In the mid-thirties Dali developed what he called the 
Paranoiac-Critical Method. His central idea was that paranoia is essentially a mental mechanism which can be used by the artist in a controlled way to create artistic images. Dali used the term 'paranoia' in the broad sense of a 'delusion of interpretation'. The notion of the 'persecution complex' was not essential to the definition. For him the paranoid state could be induced voluntarily and involved the subject perceiving images, ideas or events as being causally connected or as being all related to one central idea. These perceptions are internally coherent for the subject of the delusion but without meaning for an observer. Paranoiac-critical activity is a 'spontaneous method of irrational knowledge based upon the interpretive-critical association of delusional phenomena' ${ }^{8}$ This 'irrational knowledge' could be made 'concrete' by its incorporation in paintings. Examples of this include the many images with a double configuration which are found in Dali's paintings.

These are only some of the themes common to surrealism and psychoanalysis and psychiatry. Freud was by far the greatest intellectual influence on the surrealist movement. Developments in psychoanalytic technique were mirrored by developments in surrealist artistic techniques. In their productions one can often determine the influence of analytic and psychiatric concepts and classifications.
While surrealism has never had a great influence on the art and literature of these islands, it would be difficult to quantify its impact on continental and American culture. Psychoanalysis has played an increasingly important role in French psychiatry since 1968. A reexamination of surrealist concepts has also occurred. It would be a pity if psychiatrists in the UK failed to appreciate the wealth of 'psychological' interest offered by surrealist art to the interested observer.

\section{REFERENCE}

'LA ReVolution SurRÉliste (1984) An historical vignette: surrealism and anti-psychiatry. Bulletin of the Royal College of Psychiatrists, 8, 175.

${ }^{2}$ Balakian, A. (1972) Surrealism: The Road to the Absolute. Page 131. London: Unwin Books.

${ }^{3}$ Breton, A. (1969) Manifestoes of Surrealism. Page 14. University of Michigan Press.

4_ (1969) Manifestoes of Surrealism. Page 160. University of Michigan Press.

AdDes D. (1982) Dali. Page 121. London: Thames \& Hudson.

${ }^{\circ}$ Breton, A. (1978) What is Surrealism? Page 49. London: Pluto Press.

'ADEs, D. (1982) Dali. Page 82. London: Thames \& Hudson.

- (1982) Dali. Page 126. London: Thames \& Hudson.

\title{
The Premenstrual Syndrome
}

\author{
Gwyneth A. SAmpson, Middlewood Hospital, Sheffield
}

A conference on the premenstrual syndrome (PMS) was held in September 1984 in Philadelphia, USA, jointly supported by the Ethics and Values in Science and Technology (EVIST) Section of the National Science Foundation, and by a grant from the National Endowment for the Humanities (USA). Twenty-two international research workers in the area of PMS met for a week's closed workshop discussing the scientific, legal and ethical issues raised by the present attention being given to the syndrome. PMS is now popular in the USA, with many private clinics and programmes being developed. Ten of the twenty-two invited participants were from medicine (six of these were psychiatrists, two general practitioners and four gynaecologists); the remainder were sociologists, anthropologists, lawyers, physiologists, philosophers, behavioural geneticists, psychologists, social workers, criminologists and bioethicistsan indicator of the diversity of the effects of and research into premenstrual syndrome. There were three UK participants - a general practitioner, a gynaecologist, and a psychiatrist. As the UK psychiatrist I felt that two in particular of the concensus opinions reached by such a diverse group would be of interest to readers of the Bulletin.
The subgroup from those workers involved with Social Science Research and Public Policy reported:

The menstrual cycle is a normal event in the lives of most women of reproductive age. It does not disrupt their behaviour and does not disrupt their lives. A small percentage of women experience recurring menstrual-related problems, and some of these women find that those problems seriously affect their lives. Despite cases claiming an association between violent acts and the menstrual cycle, there are no studies confirming this. It is a violation of the dignity of all women to perpetuate stereotypes about the effect of menstruation on behaviour.

Regardless of aetiology, the experience of cyclic symptoms is an important and sometimes a serious one. We need to recognise women's experiences of these recurring symptoms and not dismiss them as figments of their imagination. At the same time, we need to distinguish these problems from other problems that have been mistakenly called PMS.

Unfortunately, the nature of the phenomenon called PMS remains ill-defined. Various aspects of the menstrual cycle need further interdisciplinary investigation. Psychological research shows clearly that using self-reports results in biases of various sorts. Social and cultural factors influence women's reported experiences and memories of them. This conclusion is shown by the research indicating that women's reported experiences vary as a 